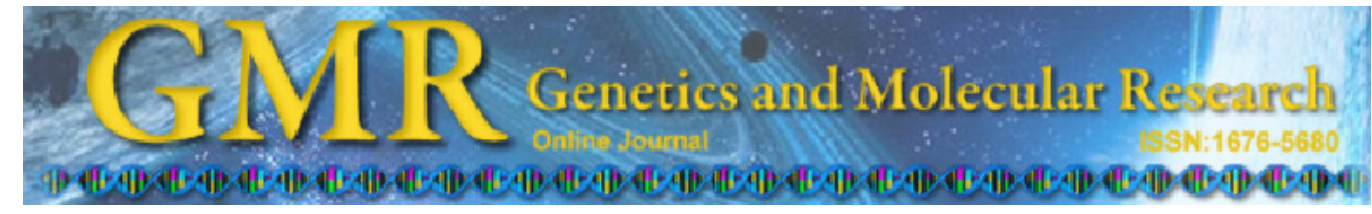

\title{
A phytotoxin Solanapyrone-A downregulates calcium-dependent protein kinase activity in potato
}

\author{
A. Hassan ${ }^{1}$, N. Hatsugai ${ }^{2}$ and M.M. Shah ${ }^{1}$ \\ ${ }^{1}$ Biotechnology Program, Department of Environmental Sciences, \\ COMSATS Institute of Information Technology, Abbottabad, Pakistan \\ ${ }^{2}$ Research Center for Cooperative Projects, Hokkaido University, \\ Kita-ku, Sapporo, Japan \\ Corresponding author: M.M. Shah \\ E-mail: mmshah@ciit.net.pk
}

Genet. Mol. Res. 12 (2): 1540-1545 (2013)

Received May 3, 2012

Accepted November 28, 2012

Published May 13, 2013

DOI http://dx.doi.org/10.4238/2013.May.13.7

\begin{abstract}
We previously demonstrated that alternaric acid, a host-specific toxin produced by the plant pathogenic fungus Alternaria solani, in the presence of $\mathrm{Ca}^{2+}$ and $\mathrm{Mg}^{2+}$, stimulated in vitro phosphorylation of His-tagged calcium-dependent protein kinase 2 from potato cultivar Rishiri (RiCDPK2). Herein, we report that Solanapyrone-A (SpA), a non-host-specific toxin produced by $A$. solani, inhibited the phosphorylation of RiCDPK2 in the presence of $\mathrm{Ca}^{2+}$ and $\mathrm{Mg}^{2+}$. However, SpA stimulated RiCDPK2 phosphorylation in the absence of these cations. Based on the current findings, we suggest that RiCDPK2 may mediate SpA-induced signaling independent of $\mathrm{Ca}^{2+}$ and $\mathrm{Mg}^{2+}$, leading to a compatible interaction between potato and $A$. solani.
\end{abstract}

Key words: Alternaria solani; CDPK; Potato; Solanapyrone-A; Solanum tuberosum x S. demissum; Suppressor 


\section{INTRODUCTION}

Biological toxins are important factors in disease development; toxins cause physiological changes in host cells such as alteration in cell membrane permeability leading to rapid increase of electrolyte loss (Otani et al., 1995). Treatment of potato tuber slices with alternaric acid, a host-specific toxin (HST), resulted in delayed cell death when infected with an incompatible species of Phytophthora infestans, suggesting that alternaric acid acts as a suppressor of hypersensitive defense response (HR). To better understand the role of toxins related to HR in potato as well as their relation to suppressors of HR in the interaction of potato and P. infestans, we investigated the effect of Solanapyrone-A (SpA; Ichihara et al., 1985; Oikawa et al., 1998), a non-host-specific toxin (NHST) from Alternaria solani, on the phosphorylation of purified RiCDPK2 (Hassan et al., 2000), a new isoform of the calcium-dependent protein kinase (CDPK) gene family from potato $\mathrm{cv}$. Rishiri $\left(\mathrm{R}_{1}\right.$-gene), which is speculatively localized to the cytosol of the cell (Okuta et al., 1999). We also examined the effect of $\mathrm{Ca}^{2+}$ and $\mathrm{Mg}^{2+}$ on the interaction of SpA and RiCDPK2. Additionally, we examined HSTs as determinants of pathogen compatibility with respect to the ability of SpA to inhibit HR-related signaling. Our results indicated that $\mathrm{SpA}$ may play a role in regulating toxin-CDPK interaction by influencing phosphorylation of RiCDPK2 independent of $\mathrm{Ca}^{2+}$ and $\mathrm{Mg}^{2+}$.

\section{MATERIAL AND METHODS}

\section{SpA preparation}

SpA used in this study was purified from cultured fluid of $A$. solani as reported previously (Ichihara et al., 1983; Langsdorf et al., 1989). The fungus was grown in potato glucose medium at $25^{\circ} \mathrm{C}$ for 25 days. The chloroform extract of the culture filtrate was subjected to silica gel column chromatography and $\mathrm{SpA}$ was eluted with a mixture of benzene and ethyl acetate. The biological effect of SpA on plant leaves was studied using fully expanded compound leaves obtained from tomato cv. Fukuju-II. Leaves were disinfected with $0.05 \%$ sodium hypochlorite and rinsed several times with distilled water. The surfaces of 2 leaves per plant were gently punctured uniformly over an area of $\sim 15 \mathrm{~mm}^{2}$ with a needle before SpA treatment. Each leaf was treated with $30 \mu \mathrm{L} \mathrm{SpA}$ in different concentrations $(0.1,0.25,2.5$, and $25 \mathrm{mM})$ and incubated in aseptic moist conditions at $25^{\circ} \mathrm{C}$ under a 14-h light period. The leaves were assessed for initiation of necrosis $24 \mathrm{~h}$ after $\mathrm{SpA}$ treatment.

\section{His-RiCDPK2 preparation}

Full-length RiCDPK2 cDNA (1488 bp, DDBJ accession No. AB0551809) was cloned into the pCR-expression vector (Invitrogen, Carlsbad, USA) and transformed into Escherichia coli (BL21 pLysS) for expression. Purification was achieved using a histidine affinity column as per manufacturer instructions. Purified RiCDPK2 was dialyzed extensively using $10 \mathrm{mM}$ Tris- $\mathrm{HCl}$ ( $\mathrm{pH} 8.0,0.1 \%$ Triton X-100). The final protein concentration, which ranged from 80 to $100 \mu \mathrm{g} / \mathrm{mL}$, was determined with the Bio-Rad (Hercules, CA, USA) protein assay kit according to Bradford (1976) using bovine serum albumin as a standard. 


\section{Phosphorylation assay}

Purified RiCDPK2 was used for the phosphorylation assay and the effect of SpA on the protein was studied in vitro using the previously reported method (Furuichi et al., 1994). Assays were performed on a 96-well microtiter plate with a total volume of $155 \mu \mathrm{L} / \mathrm{well}$. Assays were triggered by adding adenosine triphosphate (ATP; final concentration $0.9 \mathrm{mM}$ ) followed by incubation for $10 \mathrm{~min}$ at $30^{\circ} \mathrm{C}$. Subsequently, 1-naphthol $(0.2 \%$, Wako, Tokyo, Japan) dissolved in stock alkali solution (1.5 M NaOH, 0.7 $\mathrm{M} \mathrm{Na}_{2} \mathrm{CO}_{3}$ ) and 2,3-butanedione $(0.06 \%$, Wako $)$ was added to each sample for color development. Absorbance was determined in the microplate reader (BioRad 3500) at $595 \mathrm{~nm}$ with 10-min intervals for $40 \mathrm{~min}$. The temperature was maintained at $30^{\circ} \mathrm{C}$ during the reading intervals.

\section{RESULTS AND DISCUSSION}

In the biological assay, necrosis of tomato leaves was not observed until 5 days after $\mathrm{SpA}$ treatment (Figure 1). The visible concentration-dependent effect of SpA appeared much later compared to our earlier study with alternaric acid (AA) in which necrotic symptoms visibly appeared within $24 \mathrm{~h}$ after AA treatment. These observations were indicative of the fact that SpA was not active during the early period of infection, and became active at a later stage after 5 days of infection. In contrast, the detection of AA in the germination fluid of the fungus suggested its possible role during the early period of infection (Langsdorf et al., 1990; Langsdorf et al., 1991).
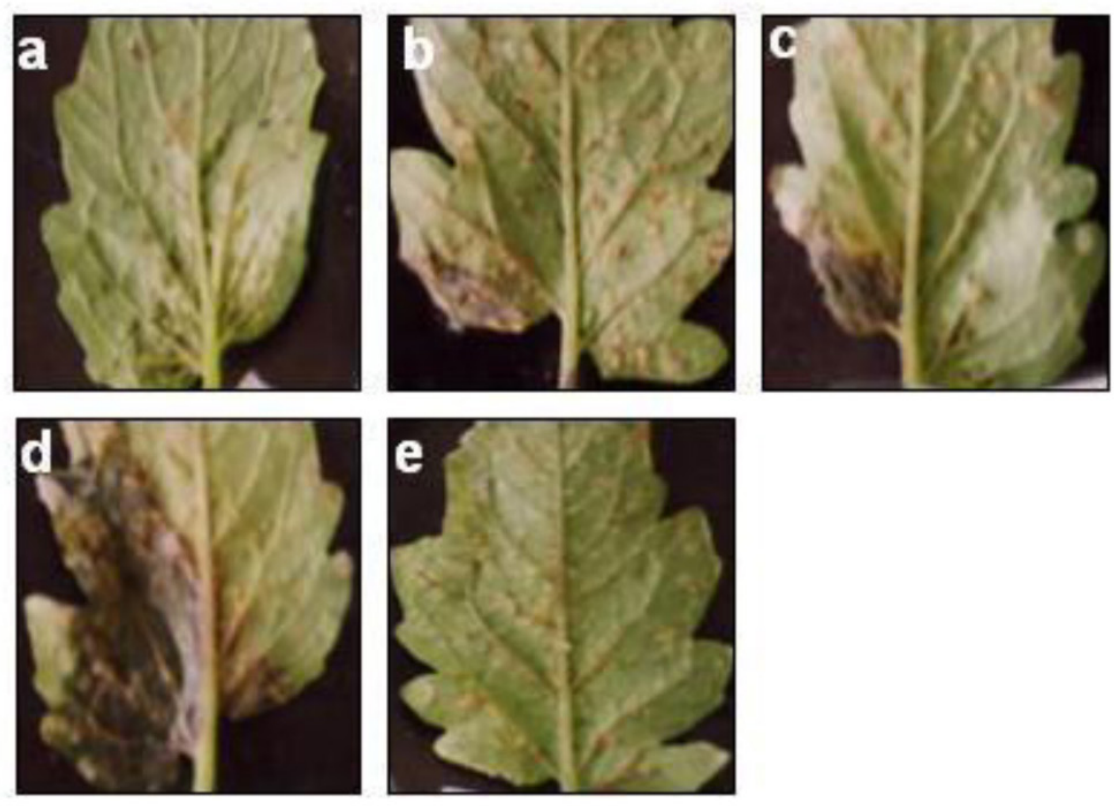

Figure 1. Biological assay of the effect of Solanapyrone-A (SpA) on tomato leaves. The leaf surface was gently punctured with a needle and treated with micromolar concentrations of SpA. Observations were made 5 days after $\mathrm{SpA}$ treatment. Treated leaves were incubated in aseptic moist conditions at $25^{\circ} \mathrm{C}$ under a $14-\mathrm{h}$ light period. SpA concentrations: a. $0.1 \mu \mathrm{M}$; b. $0.25 \mu \mathrm{M}$; c. $2.5 \mu \mathrm{M}$; d. $25 \mu \mathrm{M}$; e. control (water only). 
To determine whether purified RiCDPK2 exhibits $\mathrm{Ca}^{2+}$ - and $\mathrm{Mg}^{2+}$-dependent phosphorylation, the phosphorylation experiments were conducted both in the absence and presence of $100 \mu \mathrm{M} \mathrm{Ca}^{2+}$ alone or with $\mathrm{Ca}^{2+}$ and $0.9 \mathrm{mM} \mathrm{Mg}^{2+}$ together added concurrently with ATP. RiCDPK2 phosphorylation was stimulated to approximately $50 \%$ immediately after $\mathrm{Ca}^{2+}$ addition and to approximately $60 \%$ when $\mathrm{Ca}^{2+}$ and $\mathrm{Mg}^{2+}$ were added together (Figure 2a). In similar experiments, effect of $25 \mu \mathrm{M}$ SpA on RiCDPK2 phosphorylation was also investigated. RiCDPK2 phosphorylation immediately increased up to $43 \%$ in the presence of SpA (Figure 2b). Stimulation of phosphorylation was sustained even after $40 \mathrm{~min}$. The effect of $\mathrm{SpA}$ on RiCDPK2 phosphorylation was then measured in the presence or absence of either $\mathrm{Ca}^{2+}$ or $\mathrm{Ca}^{2+}$ and $\mathrm{Mg}^{2+}$ together. SpA initially inhibited phosphorylation of RiCDPK2 with $\mathrm{Ca}^{2+}$ by approximately $44 \%$, which increased over time (Figure 2c), and the phosphorylation activity reached approximately the same level as that without $\mathrm{SpA}$ after $30 \mathrm{~min}$, although it was slightly stimulated at $40 \mathrm{~min}$ (Figure 2c). In the presence of both $\mathrm{Ca}^{2+}$ and $\mathrm{Mg}^{2+}, \mathrm{SpA}$ inhibited RiCDPK2 phosphorylation up to around 70\% (Figure 2d).
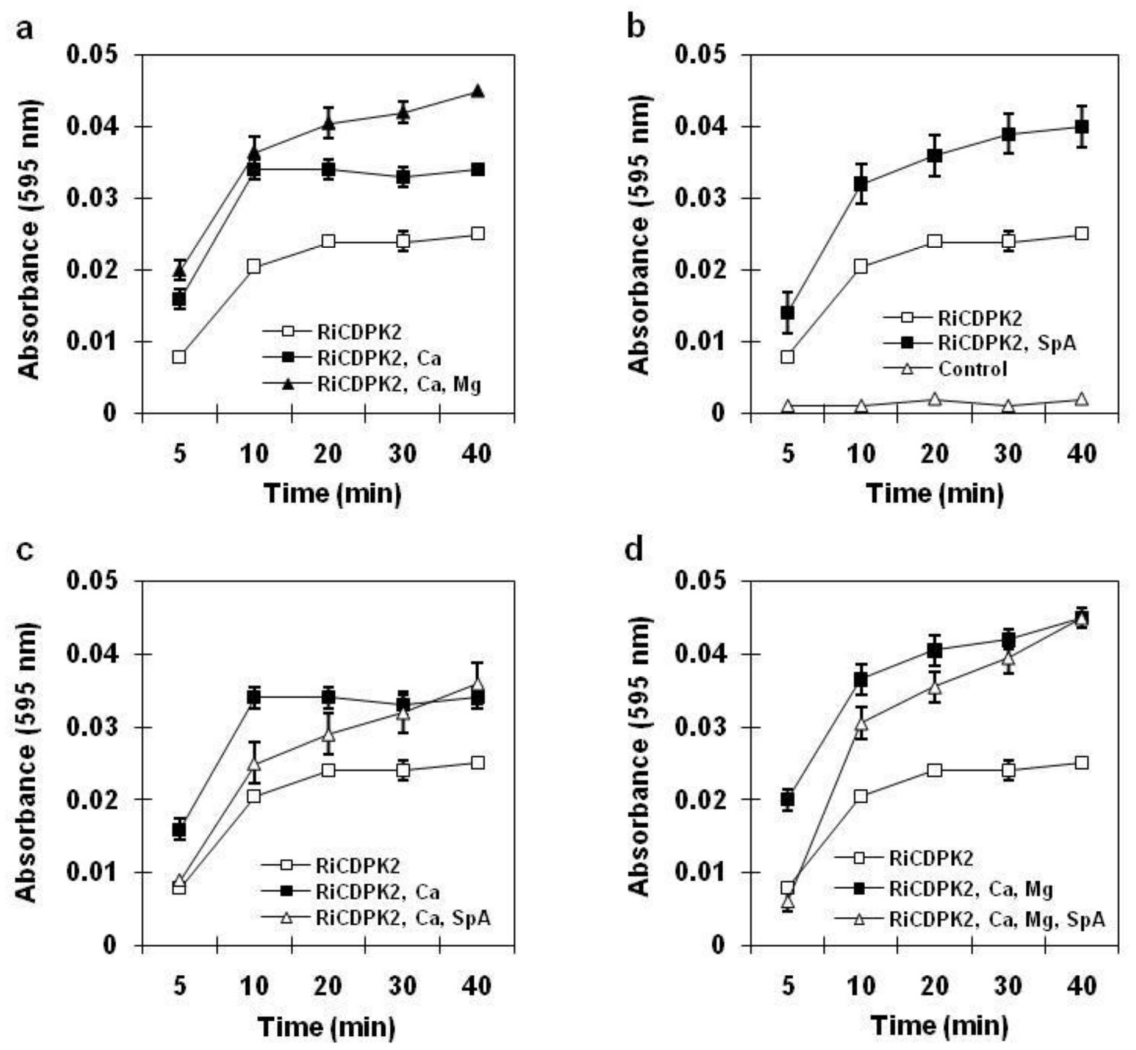

Figure 2. Effect of Solanapyrone-A (SpA), on the phosphorylation of His-RiCDPK2 in the presence of $\mathrm{Ca}^{2+}$ and/ or $\mathrm{Mg}^{2+}$. a. Effect of $\mathrm{Ca}^{2+}$ or $\mathrm{Mg}^{2+}$; b. effect of SpA; c. Effect of SpA with $\mathrm{Ca}^{2+}$; d. effect of SpA with $\mathrm{Ca}^{2+}$ and $\mathrm{Mg}^{2+}$. Final concentrations: $1.5 \mu \mathrm{g}$ RiCDPK2, $25 \mu \mathrm{M} \mathrm{SpA}, 100 \mu \mathrm{M} \mathrm{Ca}^{2+}$, and $0.9 \mathrm{mM} \mathrm{Mg}^{2+}$. The control treatment (absence of His-RiCDPK2) was identical for all the experiments in Panels a-d. Data are reported as means \pm SD for two independent experiments. 
This inhibition decreased slowly over $40 \mathrm{~min}$ and a stimulatory trend was observed after 40 min (Figure 2d). The initial inhibition (70\%) of RiCDPK2 phosphorylation by SpA with both $\mathrm{Ca}^{2+}$ and $\mathrm{Mg}^{2+}$ (Figure 2d) was more important than that of $\mathrm{Ca}^{2+}$ alone, as the infection process inflicts damage at the surface of affected cells and results in the accumulation of $\mathrm{Ca}^{2+}$ and $\mathrm{Mg}^{2+}$ at the site of infection at the early stage. Given that $\mathrm{Ca}^{2+}$ and $\mathrm{Mg}^{2+}$ stimulated RiCDPK2 phosphorylation (Figure 2a) and that SpA inhibited RiCDPK2 phosphorylation in the presence of $\mathrm{Ca}^{2+}$ and $\mathrm{Mg}^{2+}$ (Figure 2d), SpA may inhibit RiCDPK2 phosphorylation during A. solani infection in the presence of $\mathrm{Ca}^{2+}$ and $\mathrm{Mg}^{2+}$. RiCDPK2 phosphorylation in SpA-treated reactions in the presence of $\mathrm{Ca}^{2+}$ and $\mathrm{Mg}^{2+}$ increased gradually after 10, 20, 30 and 40 min (Figure 2d) as compared to the reactions without $\mathrm{Ca}^{2+}$ and $\mathrm{Mg}^{2+}$, demonstrating that these cations play an important role in stimulating RiCDPK2 phosphorylation. Moreover, a deletion mutant of the RiCDPK2 kinase domain showed weak phosphorylation activity (data not shown). In a separate study, we found that RiCDPK2 phosphorylation was inhibited by AA in the presence of $\mathrm{Ca}^{2+}$ at 5 min after treatment, but was stimulated in the presence of both $\mathrm{Ca}^{2+}$ and $\mathrm{Mg}^{2+}$ (Hassan et al., 2001). These results, together with our previous findings, suggested that AA and SpA interaction with RiCDPK2 resulted in different requirements for $\mathrm{Ca}^{2+}$ and $\mathrm{Mg}^{2+}$.

AA (Tabuchi et al., 1994), as a primary determinant of pathogenicity, mimics HSTs during disease development, showing an early effect on the plasma membrane of the host cell (Langsdorf et al., 1991; Otani et al., 1995) and is thought to play a role in the infection process leading to the suppression of HR (Langsdorf et al., 1990). Since AA significantly delayed HR in potato in a manner similar to that of a suppressor of HR derived from $P$. infestans, it was presumed that AA may stimulate RiCDPK2 activity resulting in the inhibition of HR in the host plant. While HSTs are assumed to act as suppressors of HR (Nishimura and Kohmoto, 1983; Otani et al., 1991) the role of NHSTs is yet to be clearly defined in pathogenesis. SpA is an NHST that causes necrotic lesions on the leaf of the host plant. Indeed, in our bioassay we observed that $\mathrm{SpA}$ caused necrosis in tomato leaves 5 days after treatment, contrary to AA that caused necrosis in leaves during the early period (within a few hours after treatment). Therefore, we speculated that SpA plays a role at a later stage of infection (several days after the infection process) and that SpA-mediated necrosis differed from HR, which is an early process localized to the infection site and detectable in a single cell. Furthermore, SpA inhibited RiCDPK2 phosphorylation in vitro in the presence of $\mathrm{Ca}^{2+}$ and $\mathrm{Mg}^{2+}$, while AA stimulated RiCDPK2 phosphorylation in the presence of $\mathrm{Ca}^{2+}$ and $\mathrm{Mg}^{2+}$. Our studies suggest that RiCDPK2 may mediate the signals of SpA that have a distinct role in the induction of necrosis and are most likely independent of $\mathrm{Ca}^{2+}$ and $\mathrm{Mg}^{2+}$.

\section{ACKNOWLEDGMENTS}

Research supported by the Ministry of Education, Science and Culture, Japan. The authors gratefully acknowledge the facilitation of this study by Dr. Furuichi Naotaka, Faculty of Agriculture Niigata University, Japan.

\section{REFERENCES}

Bradford MM (1976). A rapid and sensitive method for the quantitation of microgram quantities of protein utilizing the principle of protein-dye binding. Anal. Biochem. 72: 248-254. 
Furuichi N, Anderson AJ, Suzuki Y and Takemoto JY (1994). Host-Specific Toxin: Biosynthesis, Receptor and Molecular Biology. In: Elicitor and Suppressor of Phytophthora infestans Stimulate Phosphorylation of Plasma Membrane Proteins from Potato and Bean Tissues (Kohmoto K and Yoder OC, eds.). Tottori University Press, Tottori, 273-274.

Hassan A, Furuichi N, Oikawa H, Okuta T, et al. (2000). Recombinant protein preparation of calcium-dependent protein kinase gene (CPK), a receptor gene of potato for suppressor from Phytophthora infestans from potato and Arabidopsis. Jpn. J. Phytopathol. 66: 111.

Hassan A, Okuta T, Oikawa H, Ichihara A, et al. (2001). Effect of fungal metabolites on the activity of fusion protein of calcium-dependent protein kinase from potato RiCDPK2. Jpn. J. Phytopathol. 67: 125.

Ichihara A, Tazaki H and Sakamura S (1983). Solanapyrone A, B and C, phytotoxic metabolites from the fungus Alternaria solani. Tetrahedron Lett. 24: 5373-5376.

Ichihara A, Miki M and Sakamura S (1985). Absolute configuration of (-)-solanapyrone A. Tetrahedron Lett. 26: 24532454.

Langsdorf G, Furuichi N and Nishimura S (1989). Host-Specific Toxins: Recognition and Specificity Factors in Plant Disease. In: Evaluation of Alternaric Acid in Pathogenesis of Alternaria solani (Kohmoto K and Durbin RD, eds.). Tottori University Press, Tottori, 45-58.

Langsdorf G, Furuichi N, Doke N and Nishimura S (1990). Investigations on Alternaria solani infections: Detection of alternaric acid and a susceptibility-inducing factor in the spore-germination fluid of A. solani. J. Phytopathol. 128: 271-282.

Langsdorf G, Park P and Nishimura S (1991). Investigations on Alternaria solani infections: Effect of Alternaric acid on the ultrastructure of tomato cells. Ann. Phytopathol. Soc. Jpn. 57: 32-40.

Nishimura S and Kohmoto K (1983). Toxins and Plant Pathogenesis. In: Roles of Toxins in Pathogenesis (Daly JM and Deverall BJ, eds.). Academic Press, Tokyo, 135-157.

Oikawa H, Yokota T, Sakano C, Suzuki Y, et al. (1998). Solanapyrones, phytotoxins produced by Alternaria solani: biosynthesis and isolation of minor components. Biosci. Biotechnol. Biochem. 62: 2016-2022.

Okuta T, Furuichi N and Kusakari T (1999). Cloning of potato CDPK genes coding the receptor protein for the suppressor of Phytophthora infestans. Ann. Phytopathol. Soc. Jpn. 65: 327.

Otani H, Kohmoto K, Kodama M and Nishimura S (1991). Molecular Strategies of Pathogens and Host Plants. In: Role of Host-Specific Toxins in the Pathogenesis of Alternaria alternata (Patil SS, ed.). Springer-Verlag, Tokyo, 147-149.

Otani H, Kohmoto K and Kodama M (1995). Alternaria toxins and their effects on host plants. Can. J. Bot. 73: 453-458.

Tabuchi H, Oikawa H and Ichihara A (1994). Biosynthetic study of alternaric acid: isolation of plausible biosynthetic intermediates and origins of the hydrogen and oxygen atoms. J. Chem. Soc. Perkin Trans. 1: 2833-2839. 